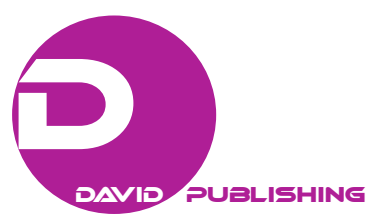

\title{
China and the United States: Mutual Trust
}

\author{
Yu Juan \\ Peking University, Beijing, China \\ China Foreign Affairs University, Beijing, China
}

\begin{abstract}
China and the United States are considered to be the most important bilateral relations in the world, and they are also the most complex one in the world. Competition, prevention and cooperation, mutual trust and mutual mapping out a different side is the current state of Sino-US relations. How to protect the mechanism of the accident but not an accident drag? How to ensure that both China and the United States have a minimum of judgment of each other's major military strategic intentions and the direction of a major national strategy? Sino-US relations and mutual trust will not lead to hostile nations. When faced with inevitable differences and competition, how can China and the United States establish an effective mutual trust to avoid conflict?
\end{abstract}

Keywords: Sino-US mutual trust, strategic intention, military relations

\section{Sino-US Military to Build a New Military Relationship to Avoid Conflict}

China and the United States are considered to be the most important bilateral relations in the world, and they are also the most complex bilateral relations. Competition, prevention and cooperation, mutual trust and mutual mapping out a different side is the current state of Sino-US relations. In the Asia-Pacific region, the United States seeks permanent advantage to continue to increase military deployment of diplomatic layout. China seeks to maintain territorial sovereignty and achieve national development. The possibility of friction between China and the United States is increasing. How to protect the mechanism of the accident is not an accident drag? How China and the United States to have a judgement of each other's major military strategic intentions and the direction of a major national strategy? Sino-US relations and trust will not become a hostile country, when faced with inevitable differences and competition, and how to establish an effective mutual trust to avoid conflict? On June 11, 2015 morning, Washington, USA, The fourth day of the Chinese Central Military Commission Vice Chairman Fan Changlong's visit to US Defense Secretary Carter in the Pentagon as the vice chairman of the Central Military Commission. Fan Changlong led Chinese military delegation held a welcoming ceremony, then the two sides held hours of closed door meetings. Fan Changlong said Sino-US military should strive to build a mutual trust and cooperation, not conflict, sustainable, the new military relations, effective management and control of the risk of attack. Carter expressed approval and said that the two sides to create a good environment for the Asia Pacific and the world, the establishment of a sustainable and practical military relation.

Military relations between China and the United States is a very important aspect of the overall relationship, which will help enhance mutual trust, not only between the two armed forces but also a mutual trust between

Yu Juan, Master, College of Foreign Languages, Peking University; Foreign Department of 2013 Postgraduate Students, China Foreign Affairs University. 
the two countries. As long as it helps to improve the relationship between Beijing and Washington, we will do it, so this visit is a good thing. We would like to have more exchanges of visits. On the last day of the public trip in June 12th, Fan Changlong visited the United States National Defense University and signed the "Sino US Army exchanges and Cooperation Dialogue Mechanism Framework" (China.org.cn, 2015).

Document, the document is also the first cooperation agreement signed between the two countries in recent years. Today marks the United States Army and the Chinese people's Liberation Army cooperation and dialogue has entered a new stage. This document will deepen cooperation to resolve the challenges of military relations, the two countries will work to create a good working relationship, increase professional communication. Although the United States and China can sometimes disagree, it is very important to keep the dialogue, especially between the two armies.

The two countries all have their own behavior, a mechanism of communication security. In fact, there is no direct confrontation between the two armies. Because the two countries are far away, unless there is a major World War II conflict between China and the United States. But in fact, the establishment of mutual exchange mechanism between the two countries will contribute to the promotion of official interaction between the two countries.

Through interactive understanding of each other's strategic intentions, enhance strategic mutual trust, in addition to the Sino-US Army exchanges and cooperation dialogue mechanism framework document", the two sides also decided to increase the naval encounter safe conduct to the memorandum of understanding on air to air content. On the memorandum of understanding, public opinion is originated in 1998 between China and the United States had signed the "on the establishment and strengthening the Military Maritime Consultative Security Mechanism Agreement", which is between the first military confidence building measures agreement, is the two countries signed the first for military security consultation agreement. More substantive significance or meet standards of conduct sea. China and the United States between the Nanhai Sea including air defense identification zone in the East China Sea, the two countries in the East China Sea between such conflict potential risk is increasing. And in fact, we remember the words, is the 2001 Sino-US collision in Hainan incident which is still visible before the eyes. So in today's strategic game between the two countries a profound and comprehensive terms, the two sides cannot afford to play another similar to the Hainan impact of such acts. So it should be said that the two sides of the strategic sector, the two sides of the military, the two countries have a sense of hope to avoid the recurrence and the occurrence of the tragedy, and then avoid military conflict between the two countries.

In fact, boh the signing of The US-China Army-to-Army Dialogue Mechanism Framework and the further enrich document of The US-China MOU on Air and Maritime Encounter are becoming more and more perfect before the vice-chairman of China's Central Military Commission, the fan Changlong visit to the United States.

\section{China and the United States to Re-examine the Relationship Between the Two Sides}

In June 2013, the two heads of state during the Anna Berg in the park during the meeting with Chinese President Xi Jinping proposed the establishment of two mutual trust mechanism initiatives, the US President Barack Obama's positive response. The mutual trust mechanism "are" the establishment of a major military operation in mutual notification of the measures of trust mechanism and the Code of Conduct and safety at sea", then defense departments of the two countries and forces through a variety of channels were more than 10 rounds of in-depth consultations and communication. Under the joint efforts, the two sides signed a 
memorandum of understanding on the mechanism of mutual trust between the two mechanisms to reach a consensus. Until November 2014, China and the United States jointly announced that the two sides have completed the signing of the text of the two mutual trust mechanism.

During the meeting between Fan Changlong and Carter, the two sides mentioned the South China Sea issue. Carter stressed that the South China Sea issue is not a problem between the United States and China, the United States on the South China Sea sovereignty dispute does not stand. And Fan Changlong also said that the South China Sea issue is Sino-US relations in an episode, both China and the United States should pay attention to long-term perspective and more major international and regional issues. For strategic security relations between China and the United States, he used the poem as a metaphor "telescope can know the small waves, soar to the skies begin to feel the "Hyperion Ping" for New China's was foundation for 60 years as the Sino-US military relations described the ups and downs, twists and turns. However, how is the strategic consideration to ensure that the military mutual trust between the two countries to go today?

If the military relation between countries is the most close to zero in the recent games, it may also be the most vulnerable part of bilateral relations. Since the establishment of diplomatic relations between China and the United States, the relationship between the two armed forces has been repeating the vicious circle of "development, stop and stop development". However, the new changes have quietly occurred.

Different from the past, the recent friction between China and the United States in the Asia Pacific region has no impact on the US. Things, but as scheduled, signed a two military mutual trust mechanism. What should we do with this change? If we simplify the problem to the classification, the current strategic mutual trust between China and the United States will be at what level?

Economic Weekly of Germany point out that the United States is not the same face towards China 20 years ago, the Sino-US relations are the world's largest economy and the relationship between the second major economies, Chinese need more American head-up. In fact, it is precisely because of this change, many of the challenges have been showing a sense of distrust to the United States together to discuss some of the issues. They question each other's goals, motivations, strategies and actions.

In 2013, Xi Jinping, Chairman of China and President Barack Obama at the Annenberg estate meeting reached to build new type of relations between China and the United States strategic consensus. Its core is not conflict, not confrontation, mutual respect, cooperation and win over the jungle law of international relations. In the United States, former Secretary of State Henry Kissinger, former Treasury Secretary Henry Paulson, Harvard professor Joseph Nye, people of insight are stressed, US-China will not repeat the great power conflict history, the United States should give the reasonable development space. Despite the positive factors are still, but the inevitable competition in the Asia Pacific is still fermenting. How China and the United States can learn to get along?

For The Role of the United States in Asia-Pacific region, the United States should make appropriate adjustments in the first place. As China has developed into a great power in a region from the past, we have more and more influence in the world. The United States must face this reality and make some corresponding policy adjustments. We need to look at the role of the Chinese need to do in this region and what role should be? What should we do to define the relationship between our country and these regions? What role should we play in the future? How do we deal with the relationship between the United States and the power of United States in this region? So China and the Chinese are actually going to look at it again. That is to say, to refind the structure of this relationship and what the two sides have to do now. 
At the beginning of the year, the website of the US Foreign Policy published the "Pacific force index" report for the first time and slected the top 50 people who shape of the future bilateral ties of Sino-US. Both the political and business man of the hour, silently labor workers in Dongguan, China Internet opinion leaders, and also the NBA star, American professor of Chinese, Chinese market has enthusiastically embraced the American mayor, and so on. This is a pastiche of the list shows the "Sino-US relations in the folk". How to build a strategic mutual trust between China and the United States in the adjustment and change? The answer to this question is not only in the temple in the folk.

In 2014, bilateral trade amounted to $\$ 555$ billion 100 million, over $\$ 120$ billion investment stock record. Four million 300 thousand people between the two countries, there is a flight every 17 minutes to take off and land every day, there are two million trips to and from the ocean on both sides of the ocean.

In 2014, the US dollar's first meeting in Beijing, on business, tourism, foreign student visa to reach a mutually beneficial arrangement. Student visa extension to five years, business and tourist visa extended to 10 years, which greatly facilitates the two companies to invest and personnel exchanges between the two countries. In the Gulf of Aden, hanging flag and the flag of warships, common to escort merchant ships; the face of global warming, the two sides signed the Sino-US joint statement on climate change. When the Ebola outbreak in Africa, the Sino-US joint rescue to the affected areas. Chinese aid supplies arrived in the country at the Liberia airport, the scene is the unloading of US troops to help the media become a favourite tale.

Today, a third of the Sino-US economic volume accounted for the world, the population accounts for a quarter of the world, the trade volume accounted for one-fifth of the world, the last year for the global economy new contribution rate reached more than $40 \%$ in today's world is worthy of the name "big guy". It is difficult to imagine that if the two sides do not cooperate, the world will be how? In the context of accelerated evolution of globalization and the deepening of Sino-American interests, both sides are aware of the two.

It is also based on this understanding to promote the Sino-US strategic mutual trust. We believe that the economic relationship between China and the US is embodiment of the blend of interests between China and America, a new type of relations between China and the United States the profound economic connotation, and the overall China US relations ballast stones and propulsion. Because of the interests of the Chinese and American people blend, so the development of Sino-US relations and its sustainability can have a solid foundation of strong public opinion between the two peoples.

\section{"Flagship" Role in the Sino-US Strategic Dialogue Mechanism}

On June 23rd, 2015, the seventh round of Sino-US strategic and economic dialogue and the sixth round of Sino-US cultural exchanges between China and the United States was held in Washington, D.C. The two countries will deepen the cooperation in the field of economic and military and cultural exchanges between the two countries to expand economic and military relations. CNN quoted a senior US official as saying the talks were designed to talk about the differences between the two sides. And then see if you can reduce differences, at least to ensure that there are differences in the field of communication, so that the two sides will not misunderstand, miscarriage of justice. In this regard, the two sides have a consensus and attaches great importance to this from the scale of the group can be seen.

Liu Yandong, vice premier of the State Council of China, Wang Yang, vice premier of the State Council of China, State Councilor and Foreign Minister Yang Jiechi, the United States Vice President Joe Biden, Secretary of state, Treasury Secretary Jacob Lu attended. In addition, the Chinese side has sent 40 ministerial 
level officials, the United States has sent nearly 20 departments responsible person to participate in the talks.

US Assistant to the Asia Pacific Affairs Russell, said the Sino-US strategic and economic dialogue between the two countries has become the dominant role of all dialogue mechanism flagship (Reuters, 2015). The two countries are using this platform to strengthen coordination and cooperation, reduce and manage differences. This system goes to today, apart from the original economic dialogue and strategic dialogue, then the two be made one. From the history of the world is probably rare. For example, put three deputy national level leaderships, two deputy prime ministers and a state councilor of China and the three mechanisms together to the cooperation need to deal with the problem between China and the United States are put up in-depth discussions.

The system can ensure that the relationship between the two countries can be relatively good deal with the problem and maintain the right track to go along the right direction.

In February 2015, Chinese President Xi Jinping received a state visit to the United States in September, the United States President Barack Obama's invitation. After 2013, the sunnylands estate tie meeting and 2014 ying'tai Nocturne, the heads of the two countries will meet again. And the Sino-US strategic and economic dialogue is also a meeting between the two heads of state to create an atmosphere, refining and preparation results.

From the beginning of 2012, what we can see is that the leaders of the two countries are visiting each year: In 2012, it was Chairman Xi Jinping as vice-chairman of China to visit the United States; 2013 was Sunshine Manor Meeting; and 2014 was the United States President Barack Obama's visit to Beijing. If this year President Obama invited Chairman Xi after attending the General Assembly of the United Nations to visit the United States, in accordance with the conventional Barack Obama President of the United States to attend the G-20 in China Summit in 2017. In this view, from 2012-2016, expect the annual meeting in international occasion of the third party, the leaders of the two countries are in the implementation of the meeting each year.

It is through such a high frequency of the two heads of state to grasp the Sino US relations, the development of a stable direction can be better to deal with the thorny issue.

And just before the Sino-US strategic and economic Dialogue held in the South China Sea, and network security issues such as the United States intends to reduce the tone. On June 18th, 2016, the US State Department Assistant Secretary of state for Asia Pacific Affairs Russell said the United States will never engage in military confrontation with China. This is not in the interest of either party. The South China Sea issue is not a problem between China and the United States. It is a problem between China and other countries. The United States supports diplomatic channels to resolve disputes in the South China Sea (Netease International News, 2015).

In addition, Russell said that China and the United States are vulnerable to cyber attacks to cooperate to deal with.

\section{Conclusions}

The United States in the face of China's development, the Institute of international issues of China, director Yuan Zongze thinks that their feeling is mixed. On the one hand, they hope China to the assumed more responsibility and play a greater role; On the other hand, the development of China makes them worried about the superiority or advantage may gradually erode away. They often say that China will not eat up American lunch. In fact, pelase d not forget a very good fact: The Chinese people are the world's greatest chefs, our 
Chinese food is all over the world. So in fact, China and the United States can make the world's best dishes and come together to enjoy such a food.

This year is the 36th anniversary of the establishment of diplomatic relations of Sino-US, and has been, or is approaching. It's a good time for both sides to look at each other again. To borrow the words of the United States experts Yang Jiemian, with a magnifying glass to see the problem of Sino-US relations are everywhere, but if you look at the telescope, the US and China relations have been moving forward. Sino-US relation is in an expected variable course. Fortunately, the two sides basically formed a consensus: is not confrontation, conflict, in this premise, the two countries to build strategic mutual trust and work every step, have extraordinary significance.

\section{References}

China.org.cn. (June 14, 2015). China, US sign army-to-army dialogue mechanism. Retrieved from http://www.china.org.cn/world/2015-06/14/content_35816706.htm

Netease International News. (2015). US initiative to reduce the tone: Never military confrontation in the South China Sea and China. Retrieved from June 20, 2015, from http://war.163.com/15/0620/10/ASI1HJ1F00014OMD.html

Reuters. (2015). China's Xi to make first state visit to US as both flag problems. Retrieved from http://www.reuters.com/article/us-usa-china-idUSKBNOLF05X20150211 